\title{
PENERAPAN METODE PEMBELAJARAN COOPERATIVE INTEGRATED READING AND COMPOSITION (CIRC) UNTUK MENINGKATKAN HASIL BELAJAR DALAM MENEMUKAN KALIMAT UTAMA PADA SISWA KELAS IV SDN 22 MATARAM TAHUN PELAJARAN 2020/2021
}

\author{
H. M. Muksin \\ SD Negeri 22 Mataram, NTB, Indonesia
}

\begin{abstract}
ABSTRAK
Rendahnya kemampuan siswa dalam memahami isi wacana berimplikasi pada rendahnya hasil belajar siswa dalam menemukan kalimat utama. Begitu juga halnya dengan kenyataan yang terjadi pada siswa kelas IV SDN 22 MATARAM tahun ajaran 2020/2021. Berdasarkan hasil wawancara dan observasi terhadap guru dan siswa kelas IV SDN 22 MATARAM tahun ajaran 2020/2021, diperoleh data hasil belajar siswa pada subpokok bahasan "menemukan kalimat utama dalam paragraf" yaitu 37,84\% atau 14 siswa yang mencapai KKM, sedangkan 23 siswa belum mencapai KKM dan dinyatakan tidak tuntas. Selama observasi ditemukan fakta bahwa kurangnya keterampilan guru dalam menggunakan metode pembelajaran yang dapat menarik minat siswa menyebabkan kurangnya motivasi, konsentrasi dan interaksi siswa dalam belajar, sehingga hasil belajar yang diperoleh kurang memuaskan. Berdasarkan masalah tersebut, salah satu pemecahan masalah yang ditawarkan penulis untuk diteliti adalah penerapan metode pembelajaran Cooperative Integrated Reading and Composition (CIRC) pada kelas IV SDN 22 MATARAM tahun ajaran 2020/2021. Adapun masalah yang ingin dikaji penulis dalam penelitian ini adalah bagaimanakah peningkatan aktivitas siswa melalui penerapan metode pembelajaran Cooperative Integrated Reading and Composition (CIRC) serta bagaimanakah peningkatan hasil belajar dalam menemukan kalimat utama melalui penerapan metode pembelajaran Cooperative Integrated Reading and Composition (CIRC) pada siswa kelas IV SDN 22 MATARAM tahun ajaran 2020/2021? Penelitian ini merupakan jenis penelitian tindakan kelas (Action Research). Metode pengumpulan data yang digunakan dalam penelitian ini adalah metode observasi, tes dan dokumentasi. Sementara itu metode yang digunakan untuk mengolah data aktivitas guru dan siswa serta hasil belajar siswa adalah menggunakan metode pendekatan kuantitatif. Hasil penelitian menunjukkkan adanya peningkatan aktivitas siswa dalam pembelajaran melalui penerapan metode pembelajaran Cooperative Integrated Reading and Composition (CIRC) yaitu pada siklus I diperoleh kriteria aktivitas siswa "cukup aktif" kemudian meningkat pada siklus II menjadi "sangat aktif". Sementara itu dari segi hasil belajar siswa juga menunjukkan peningkatan pada setiap siklus, pada siklus I hanya 52,77\% siswa yang mencapai KKM kemudian meningkat pada siklus II menjadi 91,89\% siswa yang mencapai KKM yang ditetapkan sekolah. Sehingga dapat ditelaah bahwa terjadi peningkatan hasil belajar siswa dari siklus I ke siklus II sebesar 39,12\%, ini menandakan bahwa penggunaaan metode pembelajaran Cooperative Integrated Reading and Composition (CIRC) berhasil meningkatkan hasil belajar siswa dalam menemukan kalimat utama pada siswa kelas IV SDN 22 MATARAM tahun ajaran 2020/2021.
\end{abstract}

Kata Kunci: metode pembelajaran cooperative integrated reading and composition, hasil belajar, kalimat utama.

\section{Pendahuluan}

Pelajaran bahasa memiliki peran yang sentral dalam perkembangan intelektual, sosial, emosional peserta didik dan merupakan penunjang keberhasilan dalam memelajari semua bidang studi. Pelajaran bahasa Indonesia diarahkan untuk meningkatkan kemampuan peserta didik untuk berkomunikasi dalam Bahasa
Indonesia dengan baik dan benar, baik secara lisan maupun tulisan (Syukur, 1984:12).

$\begin{array}{lcr}\text { Standar } & \text { Kompetensi mata pelajaran } \\ \text { bahasaIndonesia } & \text { merupakan } & \text { kualifikasi } \\ \text { kemampuanminimal peserta didik yang } \\ \text { menggambarkanpenguasaan }\end{array}$
keterampilanberbahasa, dan sikap positif terhadap bahasaserta sastra Indonesia. Standar kompetensi ini merupakan dasar bagi peserta didik 
untukmemahami dan merespon situasi lokal, regional, nasional, dan global (Direktorat Pembinaan TK/SD, 2006:317).

Sesuai dengan kurikulum yang berlaku saat ini, ruang lingkup mata pelajaran bahasa Indonesiamencakup komponen kemampuan berbahasa dan kemampuan bersastra meliputi aspek-aspek: mendengarkan, berbicara, membaca, danmenulis yang diuraikan melalui standarkompetensi yang harus dicapai peserta didik.

Keterampilan berbahasa haruslah ditanamkan sejak dini pada diri seseorang agar tidak mudah terpengaruhi oleh perkembangan zaman. Usia sekolah dasar adalah usia yang sangat cocok untuk pembentukan karakter seseorang sebab pada usia ini anak sudah mulai lancar dalam hal menulis, membaca, berbicara dan mendengarkan. Anak sekolah dasar usia 7-13 tahun adalah usia yang tepat untuk menanamkan konsep berbahasa. Karena pada usia ini anak sudah mampu bersoasialisasi dengan orang lain. Pada usia ini anak haruslah dibimbing agar mampu berkomunikasi dengan orang lain secara baik (Suprijono, 2009:23).

Salah satu standar kompetensi yang harusdicapai peserta didik tingkat SD kelas IV adalah "Menemukan ide pokok atau kalimat utama dalam paragraf". Kegiatan untuk menemukan kalimat utama dalam paragraf bagi sebagian besar siswa masih merupakan kegiatanyang tergolong sulit. Dalam kegiatan belajar mengajar, siswa sering menghadapi soalsoal yang berkaitan dengan materi membaca wacana atau paragraf. Akan tetapi, kelihatannya siswa kurang berminatmembaca wacana secara cermat sehinggaberdampak pada hasil tes membaca yang sangat rendah.

Menemukan kalimat utama merupakanbagian dari keterampilan membaca yang harus digali agar peserta didik dapat meningkatkanketerampilan berbahasa mereka, khususnyadalam hal membaca dan menemukan kalimatutama sebuah paragraf.

Kenyataan dilapangan ternyata proses belajar mengajar untukmelatih keterampilan dan meningkatkan hasil belajar siswa dalam menemukan kalimat utama dari suatu paragraf atau wacanamasih menjadipersoalan yang besar. Apakah permasalahanada pada guru yaitu rendahnya daya kreasiguru dalam pembelajaran atau dari siswa yangkurang mampu merumuskan kalimat utama darisebuah paragraf atau wacana.

Begitu juga halnya dengan kenyataan yang terjadi di SDN 22 MATARAM, hampir sebagian besar siswa kelas IV belum mampu menemukan kalimat utama dalam paragraf. Hal ini disebabkan karena kurangnya tingkat pemahaman siswa dalam membaca dan memahami isi sebuah paragraf.

Hasil observasi selama proses belajar mengajar di kelas berlangsung, guru tidak menggunakan metode atau model pembelajaran yang dapat menarik minat siswa terhadap materi pelajaran bahasa Indonesia. Guru hanya menggunakan metode ceramah dan tanya jawab, dalam hal ini ceramah lebih banyak dari tanya jawab sehingga kurang merangsang kemampuan berpikir siswa. Akibatnya, siswa kurang berperan aktif dalam pembelajaran, kurang konsentrasi, tidak ada interaksi antar siswa, dan tidak ada inisiatif dari siswa untuk menanyakan hal-hal yang belum dimengerti dan dipahami kepada gurunya.

Hal ini didukung oleh hasil belajar siswa pada subpokok bahasan "menemukan kalimat utama dalam paragraf" yaitu $37,84 \%$ siswa mendapat nilai $70-80,13,51 \%$ siswa mendapat nilai $50-60$, dan $48,65 \%$ lagi mendapat nilai dibawah 50. Sementara itu, KKM yang ditentukan untuk pelajaran bahasa Indonesia di SDN 22 MATARAM adalah 70. Berdasarkan nilai di atas berarti hanya ada $37,84 \%$ siswa atau 14 siswa yang dinyatakan lulus, dari jumlah keseluruhan siswa kelas IV yaitu 37 siswa.

Salah satu pemecahan berbagai permasalahan yang dapat digunakan dalam rangka peningkatan kualitas pendidikan adalah pemanfaatan atau penelitian pendidikan. Penelitian pendidikan diantaranya adalah penelitian tindakan kelas. Tindakan kelas yaitu suatu kajian yang bersifat reflektif oleh pelaku tindakan yang dilakukan untuk meningkatkan kemampuan rasional dari tindakan-tindakan yang dilakukannya itu, serta memperbaiki proses dan 
hasil pembelajaran dimana praktek-praktek pembelajaran tersebut dilakukan.

Penelitian tindakan kelas tersebut merupakan suatu cara yang strategis bagi guru untuk memperbaiki atau meningkatkan layanan pendidikan yang dilaksanakan dalam konteks pembelajaran di kelas. Oleh karena itu, diperlukan jembatan berpikir dengan menggunakan teknik maupun metode pembelajaran yang mampu menciptakan suasana yang menarik agar merangsang kemampuan berpikir serta menambah pengalaman belajar siswa dan berdampak pada peningkatan kemampuan menemukan kalimat utama dalam paragraf.

Banyak hal yang dapat dilakukan guru dalam hal mengaktifkan siswa, baik dengan menggunakan media, strategi, pendekatan, metode maupun model pembelajaran untuk merangsang kemampuan siswa dalam berpikir, dan yang tidak kalah pentingnya anak akan mampu menerapkan apa yang didapatkan di sekolah ke dalam kehidupan sehari-harinya dan mampu mencerminkan sikap yang baik serta sopan.

Memilih metode-metode pembelajaran yang baik dan tepat untuk sebuah pembelajaran adalah salah satu upaya yang harus dilakukan seorang guru agar mampu mencapai tujuan pembelajaran. Berkaitan dengan tujuan pembelajaran bahasa Indonesia, perlu diterapkan suatu metode pembelajaran yang efektif dan menunjang kegiatan pembelajaran. Metode pembelajaran yang beraneka ragam menyebabkan guru harus selektif memilih model pembelajaran secara tepat. Salah satu faktor yang mempengaruhi penentuan metode pembelajaran adalah materi pembelajaran. Metode yang efektif untuk pengajaran materi satu belum tentu efektif untuk mengajarkan materi yang lain. Setiap materi mempunyai karakteristik yang menentukan metode pembelajaran yang digunakan untuk materi tersebut.

Salah satu metode yang dapat digunakan dalam pembelajaran bahasa Indonesia khususnya pada subpokok bahasan menemukan kalimat utama dalam paragraf yaitu menerapkan metode pembelajaran Cooperative Integrated Reading and Composition (CIRC).
Metode pembelajaran Cooperative Integrated Reading and Composition (CIRC) yaitu mengarang dan membaca terintegrasi yang kooperatif. CIRC adalah salah satu model pembelajaran Cooperative Learning yang khusus diterapkan pada pembelajaran membaca dan menulis di sekolah. Metode ini mendorong siswa berperanserta secara aktif sehingga pembelajaran membaca menjadi lebih menarik, dinamis, danmenyenangkan.

Berdasarkan uraian permasalahan tersebut, secara umum permasalahan penelitian ini adalah sebagai berikut: 1) Bagaimanakah peningkatan aktivitas siswa melalui penerapan metode pembelajaran Cooperative Integrated Reading and Composition (CIRC)? 2) Bagaimanakah peningkatan hasil belajardalam menemukan kalimat utama melalui penerapan metode pembelajaran Cooperative Integrated Reading and Composition (CIRC)pada siswa kelas IV SDN 22 MATARAM tahun ajaran 2020/2021?

Adapun tujuan dari penelitian ini adalah sebagai berikut: 1) Untuk meningkatkan aktivitas siswa melalui penerapan metode pembelajaran Cooperative Integrated Reading and Composition (CIRC); 2) Untuk meningkatkan hasil belajar dalam menemukan kalimat utama melalui penerapan metode pembelajaran Cooperative Integrated Reading and Composition (CIRC) pada siswa kelas IV SDN 22 MATARAM tahun ajaran 2020/2021?

Penelitian ini merupakan wujud nyata terhadap pengembangan ilmu pengetahuan dalam rangka penyelenggaraan proses pembelajaran efektif yang menekankan pada partisipasi aktif siswa sebagai warga belajar.

\section{Pembahasan}

Seorang peneliti harus mampu menentukan subjek penelitian karena dari mereka akan memberikan informasi tentang objek atau masalah yang diteliti. Mengingat pentingnya subjek penelitian, maka untuk menentukannya ada beberapa cara yang dapat ditempuh, namun demikian terlebih dahulu harus diketahui makna 
populasi dan sampel secara teoritis untuk menentukan subjek penelitian.

Pengertian populasi menurut Sugiyono (2000: 55) merupakan wilayah generalisasi yang terdiri atas objek atau subjek yang mempunyai kuantitas dan karakteristik tertentu yang diterapkan oleh peneliti untuk dipelajari dan kemudian ditarik kesimpulannya. Sedangkan menurut Fraenkel dan Wallen dalam (Riyanto, 2001: 63) populasi mengandung arti kelompok yang menarik peneliti, di mana kelompok tersebut oleh peneliti dijadikan sebagai subjek untuk menggeneralisasikan hasil penelitian. Menurut Arikunto (1996: 115) populasi adalah keseluruhan subjek penelitian. Apabila seseorang ingin meneliti semua elemen yang ada dalam wilayah penelitian, maka penelitiannya adalah penelitian populasi. Studi penelitian juga disebut studi populasi atau studi sensus.

Berdasarkan uraian di atas, dapat disimpulkan bahwa populasi merupakan semua subjek, objek, individu atau peristiwa yang lengkap, jelas dan diamati serta memenuhi syaratsyarat tertentu dalam suatu penelitian.

Mengingat jumlah siswa kelas IV SDN 22 MATARAM kurang dari 100, maka penelitian ini disebut studi populasi. Hal ini berpangkal dari pendapat Arikunto (2002: 112) yang menjelaskan bahwa untuk sekedar ancer-ancer maka apabila subjeknya kurang dari 100 lebih baik diambil semua sehingga penelitiannya merupakan penelitian populasi.

Menurut Ridwan (2002: 24) metode pengumpulan data adalah teknik atau cara-cara yang dapat digunakan oleh peneliti untuk mengumpulkan data. Metode (cara atau teknik) menunjuk suatu kata yang abstrak dan tidak diwujudkan dalam benda tetapi hanya dapat dilihatkan penggunaannya melalui: angket, wawancara, pengamatan, ujian (tes), dokumentasi dan lainnya. Peneliti dapat menggunakan salah satu atau gabungan tergantung dari masalah yang dihadapi.

Metode observasi adalah pengamatan yang dilakukan dengan sengaja secara sistematis mengenai fenomenasosial dan gejala-gajala fisik untuk kemudian dilakukan pencatatan (Subagio, 2002 :26) sedangkan menurut Nasution (2005: 19) observasi adalah kegiatan yang dilakukan dengan memusatkan perhatian pada pusat permasalahan yang akan diteliti, untuk memperoleh informasi sesuai dengan kenyataan dan diperoleh gambaran yang jelas tentang permasalahan dan dan cara pemecahannya.

Berdasarkan pendapat di atas, maka penelitian ini observasi digunakan dalam rangka untuk membuktikan kebenaran informasi oleh peneliti sesuai dengan yang ada di lapangan yaitu dengan membuat data situasi pembelajaran diamati dengan menggunakan lembar observasi.

Metode tes adalah suatu cara untuk menilai hasil-hasil pelajaran yang diberikan guru kepada siswanya dalam jangka waktu tertentu (Purwanto, 2004 :32). Menurut Arikunto (1992: 127) tes adalah kumpulan pertanyaan atau latihan serta alat lain uang digunakan untuk mengukur keterampilan, intelegensi, kemampuan atau bakat yang dimiliki oleh individu atau kelompok. Ahli lain mengemukakan tes adalah alat yang digunakan untuk mengumpulkan data yang sifatnya mengevaluasi hasil proses (Husen, 1992: 21). Dari ketiga pendapat di atas dapat disimpulkan, tes adalah cara untuk mengumpulkan data yang berisi pertanyaan, latihan atau alat lain yang digunakan untuk mendapatkan data primer penelitian ini. Data yang dimaksudkan adalah data kemampuan menggunakan imbuhan dan kata depan dalam kalimat bahasa Indonesia dengan keterampilan menulis pada siswa kelas IV SDN 22 MATARAM. Tes yang diberikan yang diberikan terdiri atas tes berbentuk pilihan ganda dua puluh butir dan sepuluh butir soal isian.

Langkah-langkah yang digunakan peneliti dalam melakukan tes kemampuan membedakan imbuhan dan kata depan pada siswa kelas IV SDN 22 MATARAM adalah sebagai berikut: 1) Memberikan soal yang berkaitan dengan kemampuan membedakan imbuhan dengan kata depan; 2) Alokasi waktu yang disediakan 2 x 40 menit; 3) Setiap siswa ditekankan untuk menggunakan pola sesuai dengan yang dianjurkan dalam tata bahasa Indonesia; 4) Jumlah soal tiga puluh butir terdiri dari dua puluh butir soal pilihan ganda dan sepuluh butir soal isian; 5) Skor untuk pilihan ganda adalah tiap butir soal benar skor 1 
dan tiap butir soal isian benar juga skornya 1. Jadi skor maksimal untuk keseluruhan soal yaitu 30 . Untuk menghitung nilai siswa menggunakan rumus

$$
\text { Nilai }=\frac{\text { Skor yang diperoleh }}{\text { skor maksimal }} \times 100
$$

Metode dokumentasi merupakan cara mengumpulkan data dengan mencatat data-data yang sudah ada (Riyanto, 2001: 103). Menurut Arikunto (2002: 206) metode dokumentasi adalah mencari data atau hal-hal atau variable yang berupa catatan, transkrip, buku, surat kabar, prasasti, notulen rapat, legger, agenda, dan sebagainya.

Dari kedua pendapat di atas, yang dimaksud dengan metode dokumentasi adalah suatu cara untuk memperoleh data yang dilakukan dengan jalan mencatat keterangan-keterangan yang terdapat dalam dokumen-dokumen seperti daftar nilai (legger) dan catatan khusus dari guru yang terkait dengan masalah yang diteliti. Hal ini dimaksudkan untuk memperoleh data tentang nilai kemampuan siswa dalam pembelajaran bahasa Indonesia setelah dilakukan pemberian tugas menggunakan awalan dan kata depan.

Analisis data dalam suatu penelitian bertujuan untuk menyempitkan dan membatasi penemuan-penemuan sehingga menjadi suatu data yang teratur serta tersusun dan lebih berarti (Marzuki, 1986: 87).

Setelah data terkumpul selanjutnya data dianalisis dengan menggunakan hitungan statistik. Adapun langkah-langkah analisis yang dilakukan dalam menganalisis data yang telah dikumpulkan sebagai berikut:

a. Mencari kemampuan individual

1. Menentukan SMI (skor maksimal ideal)

2. SMI adalah skor maksimal yang diraih oleh siswa apabila jawabannya benar semua.

3. Menentukan mean ideal (MI) $\mathrm{MI}=1 / 2 \mathrm{xSMI}$

4. Menentukan standar deviasi ideal (SDI) $\mathrm{SDI}=1 / 3 \mathrm{xMI}$

5. Mengelompokkan taraf kemampuan siswa
a. Taraf kemampuan tinggi : $\mathrm{M}+1 \mathrm{SD}$
b. Taraf kemampuan sedang : $\mathrm{M} \pm 1 \mathrm{SD}$

c. Taraf kemampuan rendah : M - $1 \mathrm{SD}$

b. Kriteria kelompok:

$$
\begin{aligned}
& \text { 1. } \mathrm{M}=\frac{\sum \mathrm{fx}}{\mathrm{N}} \\
& \text { 2. } \mathrm{IPK}=\frac{\mathrm{M}}{\mathrm{SMi}} \times 100
\end{aligned}
$$

Keterangan:

$$
\begin{array}{ll}
\mathrm{IPK} & =\text { Indeks Prestasi Kelompok } \\
\mathrm{M} & =\text { Mean (nilai rata-rata) } \\
\mathrm{SMi} & =\text { Skor Maksimal ideal } \\
100 & =\text { Bilangan tetap }
\end{array}
$$

(Nurkancana, 1990 : 69).

Sedangkan pedoman dalam menghitung indeks kelompok digunakan interval penilaian sebagai berikut.

$$
\begin{array}{ll}
00-30 & =\text { Sangat rendah } \\
31-54 & =\text { Rendah } \\
55-74 & =\text { Normal } \\
75-89 & =\text { Tinggi } \\
90-100 & =\text { Sangat tinggi }
\end{array}
$$

(Nurkancana, 1983: 177).

Dengan menggunakan pedoman penilaian tersebut, berarti siswa yang mencapai skor mentah 75 dikategorikan nilainya tinggi, sedangkan siswa yang mencapai skor mentah $0-30$ dikategorikan sangat rendah.

\section{Pembahasan}

Persiapan pembelajaran membedakan imbuhan dengan kata depan dalam kalimat bahasa Indonesia meliputi pembuatan; program tahunan (PROTA), Program Semester (PROMES), Lembar Kerja Siswa (LKS), Penyusunan Analisis Materi Pembelajaran (AMP) membedakan imbuhan dengan kata depan dan menetapkan langkah-langkah kegiatan pembelajaran.

Persiapan pembelajaran tersebut di atas dibuat sekali dalam satu semester sebagai acuan dasar dalam melaksanakan pembelajaran menulis dalam semester pertama. Dalam penggunaan kata depan yang digunakan sebagai tugas untuk membubuhi kalimat adalah dengan, demi, dan berkat. Sedangkan dalam penggunaan awalan yang digunakan sebagai tugas untuk membubuhi kalimat adalah ber-, me-, ke-,di. Dalam hal ini soal tugas yang diberikan merupakan soal pihan ganda dan isian. 
Persiapan instrumen pembelajaran membedakan imbuhan dengan kata depan dengan metode tes dan tanya jawab. Pada tahap pembukaan dalam proses belajar mengajar ini, sebelum memulai pembelajaran tentang membedakan imbuhan dengan kata depan dalam kalimat bahasa Indonesia terlebih dahulu guru membuka pelajaran dengan salam dan melanjutkan dengan memberikan apersepsi atau mengulang kembali penjelasan materi sebelumnya tentang membedakan imbuhan dengan kata depan dalam kalimat bahasa Indonesia. Apersepsi ini dilakukan dengan tanya jawab untuk menyegarkan ingatan siswa tentang bagaimana membedakan imbuhan dengan kata depan dalam kalimat bahasa Indonesia yang benar sesuai dengan kaidah-kaidahnya, maupun menulis kalimat dengan menggunakan imbuhan dan kata depan yang baik dan benar.

Berdasarkan hasil tes yang telah dilaksanakan, diperoleh data yang menunjukan nilai siswa yang bervariasi dalam menjawab soal. Nilai siswa yang bervariasi tersebut memberikan gambaran tentang kemampuan siswa kelas IV SDN 22 MATARAM, dalam membedakan penggunaan imbuhan dengan kata depan.

Tabel 01. Data Nilai Kemampuan Siswa Kelas X IPA tentang Penggunaan Imbuhan.

\begin{tabular}{|c|c|c|c|c|c|c|c|c|}
\hline \multirow{3}{*}{ No } & \multirow{3}{*}{ Nama Siswa } & \multirow{3}{*}{ Kelas } & \multicolumn{4}{|c|}{ Aspek Penilaian } & \multirow{3}{*}{ JML } & \multirow{3}{*}{$\begin{array}{c}\text { Rata- } \\
\text { rata }\end{array}$} \\
\hline & & & 1 & 2 & 3 & 4 & & \\
\hline & & & $0-20$ & $0-20$ & 0-30 & $0-30$ & & \\
\hline 1 & AFIATUL HAIFAH & X IPA 1 & 20 & 20 & 30 & 23 & 93 & 23,25 \\
\hline 2 & BQ. NIHAL URWA & X IPA 1 & 14 & 20 & 23 & 20 & 77 & 19,25 \\
\hline 3 & DEVI ANGGUN & X IPA 1 & 20 & 20 & 28 & 27 & 95 & 23,75 \\
\hline 4 & FARIZAL RAMADHAN & X IPA 1 & 20 & 20 & 30 & 27 & 97 & 24,25 \\
\hline 5 & IRMA RAHMANI & X IPA 1 & 20 & 20 & 30 & 29 & 99 & 24,75 \\
\hline 6 & I'IN RAHMAWATI & X IPA 1 & 20 & 20 & 25 & 30 & 95 & 23,75 \\
\hline 7 & $\begin{array}{l}\text { LALU PRADIPTA NUR } \\
\text { IRFANI }\end{array}$ & X IPA 1 & 20 & 18 & 25 & 22 & 85 & 21,25 \\
\hline 8 & MUHAMMAD ZIYADI & X IPA 1 & 18 & 17 & 15 & 20 & 70 & 17,50 \\
\hline 9 & MUHAMMAD UBAEDI & X IPA 1 & 20 & 20 & 30 & 29 & 99 & 24,75 \\
\hline 10 & MIHAN & X IPA 1 & 20 & 20 & 30 & 24 & 94 & 23,50 \\
\hline 11 & $\begin{array}{l}\text { MUHAMMAD BASTIAN } \\
\text { ALI }\end{array}$ & X IPA 1 & 15 & 20 & 18 & 25 & 78 & 19,50 \\
\hline 12 & MUHAMMAD RIDHO & X IPA 1 & 20 & 20 & 28 & 27 & 95 & 23,75 \\
\hline 13 & NINI INDRIYANI & X IPA 1 & 20 & 20 & 19 & 20 & 79 & 19,75 \\
\hline 14 & NOVIA INDRAWATI & X IPA 1 & 20 & 20 & 28 & 22 & 90 & 22,50 \\
\hline 15 & NINING FUJI DIAR & X IPA 1 & 20 & 20 & 25 & 22 & 87 & 21,75 \\
\hline 16 & ROLI ADITIYA & X IPA 1 & 20 & 20 & 28 & 23 & 91 & 22,75 \\
\hline 17 & $\begin{array}{l}\text { ROHILLIANI WINA } \\
\text { SASKIA }\end{array}$ & X IPA 1 & 20 & 20 & 30 & 29 & 99 & 24,75 \\
\hline 18 & RIZQI JUNI ASRI & X IPA 1 & 20 & 20 & 29 & 30 & 99 & 24,75 \\
\hline 19 & SA'ADATUL AINI & X IPA 1 & 17 & 20 & 24 & 20 & 81 & 20,25 \\
\hline 20 & SITI ROHANIAH & X IPA 1 & 20 & 20 & 30 & 29 & 99 & 24,75 \\
\hline 21 & $\begin{array}{l}\text { SYLVIA LARANTIKA } \\
\text { PRATIWI }\end{array}$ & X IPA 1 & 14 & 18 & 20 & 22 & 74 & 18,50 \\
\hline 22 & TIA HANDAYANI & X IPA 1 & 20 & 20 & 29 & 30 & 99 & 24,75 \\
\hline 23 & NURHASANAH & X IPA 1 & 20 & 20 & 28 & 24 & 92 & 23,00 \\
\hline
\end{tabular}




\begin{tabular}{|c|c|c|c|c|c|c|c|c|}
\hline \multirow{3}{*}{ No } & \multirow{3}{*}{ Nama Siswa } & \multirow{3}{*}{ Kelas } & \multicolumn{4}{|c|}{ Aspek Penilaian } & \multirow{3}{*}{ JML } & \multirow{3}{*}{$\begin{array}{r}\text { Rata- } \\
\text { rata }\end{array}$} \\
\hline & & & 1 & 2 & 3 & 4 & & \\
\hline & & & $0-20$ & $0-20$ & 0-30 & 0-30 & & \\
\hline 24 & AHMAD ALI SYA'BANA & X IPA 1 & 20 & 20 & 30 & 28 & 98 & 24,50 \\
\hline 25 & ALI AKBAR RAFSANJANI & X IPA 1 & 20 & 20 & 30 & 28 & 98 & 24,50 \\
\hline 26 & ARMAN MAULANA & X IPA 1 & 20 & 20 & 30 & 28 & 98 & 24,50 \\
\hline 27 & AINAYAL AL FATIHA & X IPA 1 & 20 & 20 & 26 & 28 & 94 & 23,50 \\
\hline 28 & DHEVIA AURELIA & X IPA 1 & 15 & 18 & 19 & 25 & 77 & 19,25 \\
\hline 29 & ELYZA DIANTARI & X IPA 1 & 11 & 18 & 21 & 24 & 74 & 18,50 \\
\hline 30 & KHAIRUNNIDA & X IPA 1 & 20 & 20 & 26 & 18 & 84 & 21,00 \\
\hline 31 & MULIANI & X IPA 1 & 19 & 21 & 16 & 19 & 75 & 18,75 \\
\hline 32 & $\begin{array}{l}\text { MUHAMMAD BURHAN } \\
\text { AZZIS }\end{array}$ & X IPA 1 & 18 & 20 & 18 & 23 & 79 & 19,75 \\
\hline 33 & M. SOPYAN KHOLID & X IPA 1 & 16 & 18 & 20 & 24 & 78 & 19,50 \\
\hline 34 & MAWADDAH & X IPA 1 & 20 & 18 & 20 & 19 & 77 & 19,25 \\
\hline 35 & PUTRI JANUARTI & X IPA 1 & 18 & 20 & 23 & 25 & 86 & 21,50 \\
\hline 36 & RUHUL AINI & X IPA 1 & 18 & 20 & 18 & 26 & 82 & 20,50 \\
\hline 37 & RINA RIZKIANI & X IPA 1 & 20 & 18 & 19 & 20 & 77 & 19,25 \\
\hline 38 & ROSI ANJANI & X IPA 1 & 20 & 18 & 19 & 21 & 78 & 19,50 \\
\hline 39 & SUKMAWATI & X IPA 1 & 20 & 20 & 18 & 22 & 80 & 20,00 \\
\hline 40 & SYAUFRIANDA FAUZI & X IPA 1 & 20 & 20 & 24 & 30 & 94 & 23,50 \\
\hline 41 & SITI AYU AZHARY & X IPA 1 & 19 & 18 & 15 & 24 & 76 & 19,00 \\
\hline 42 & SYAMSUL HIDAYAT & X IPA 2 & 20 & 16 & 20 & 22 & 78 & 19,50 \\
\hline 43 & SAEPUL AZIS & X IPA 2 & 20 & 20 & 18 & 23 & 81 & 20,25 \\
\hline 44 & ULFA SARARESVIA & X IPA 2 & 19 & 20 & 16 & 24 & 79 & 19,75 \\
\hline 45 & ISTIHADAH & X IPA 2 & 20 & 20 & 20 & 24 & 84 & 21,00 \\
\hline 46 & $\begin{array}{l}\text { SAGITA AYU } \\
\text { RAMADIANTI }\end{array}$ & X IPA 2 & 20 & 20 & 20 & 25 & 85 & 21,25 \\
\hline 47 & ABDUL HAMID & X IPA 2 & 20 & 20 & 24 & 19 & 83 & 20,75 \\
\hline 48 & ADRIAN MAULANA & X IPA 2 & 20 & 20 & 20 & 24 & 84 & 21,00 \\
\hline 49 & AZIZAH & X IPA 2 & 20 & 20 & 20 & 20 & 80 & 20,00 \\
\hline 50 & ALAMSAH & X IPA 2 & 20 & 20 & 20 & 23 & 83 & 20,75 \\
\hline 51 & BAIQ YUDHIA IHROMI & X IPA 2 & 20 & 20 & 25 & 20 & 85 & 21,25 \\
\hline 52 & DIMAS HIJARWADI & X IPA 2 & 18 & 20 & 15 & 24 & 77 & 19,25 \\
\hline 53 & ELMANIA MONICA & X IPA 2 & 20 & 17 & 20 & 18 & 75 & 18,75 \\
\hline 54 & FITRIANI & X IPA 2 & 20 & 20 & 21 & 20 & 81 & 20,25 \\
\hline 55 & HENDRI HIDAYAT & X IPA 2 & 20 & 20 & 22 & 25 & 87 & 21,75 \\
\hline 56 & HASBIBULLAH & X IPA 2 & 20 & 20 & 17 & 21 & 77 & 19,25 \\
\hline 57 & ISMADIANA & X IPA 2 & 20 & 20 & 18 & 20 & 78 & 19,50 \\
\hline 58 & JUNIAWAN MULIADI & X IPA 2 & 20 & 20 & 17 & 20 & 77 & 19,25 \\
\hline 59 & KIKI APRILIA & X IPA 2 & 20 & 20 & 18 & 26 & 84 & 21,00 \\
\hline 60 & LUKMAN HADI & X IPA 2 & 20 & 18 & 20 & 22 & 80 & 20,00 \\
\hline 61 & $\begin{array}{l}\text { MUHAMMAD UMAR } \\
\text { SOPIANTO }\end{array}$ & $\mathrm{X}$ IPA 2 & 20 & 19 & 17 & 23 & 79 & 19,75 \\
\hline 62 & MAIL MARSAKIAWAN & X IPA 2 & 19 & 20 & 18 & 21 & 78 & 19,50 \\
\hline
\end{tabular}




\begin{tabular}{|c|c|c|c|c|c|c|c|c|}
\hline \multirow{3}{*}{ No } & \multirow{3}{*}{ Nama Siswa } & \multirow{3}{*}{ Kelas } & \multicolumn{4}{|c|}{ Aspek Penilaian } & \multirow{3}{*}{ JML } & \multirow{3}{*}{$\begin{array}{l}\text { Rata- } \\
\text { rata }\end{array}$} \\
\hline & & & 1 & 2 & 3 & 4 & & \\
\hline & & & $0-20$ & $0-20$ & 0-30 & 0-30 & & \\
\hline 63 & MUHAMMAD FAIZI & X IPA 2 & 20 & 20 & 18 & 21 & 79 & 19,75 \\
\hline 64 & MUHAMMAD SODIKIN & X IPA 2 & 20 & 20 & 27 & 24 & 91 & 22,75 \\
\hline 65 & MUHAMMAD FIKRI & X IPA 2 & 20 & 20 & 19 & 27 & 86 & 21,50 \\
\hline 66 & $\begin{array}{l}\text { MUHAMMAD TAUFIQ } \\
\text { HIDAYAT }\end{array}$ & X IPA 2 & 20 & 20 & 19 & 20 & 79 & 19,75 \\
\hline 67 & M. YAZID HAKIM & X IPA 2 & 20 & 20 & 21 & 20 & 81 & 20,25 \\
\hline 68 & MUTIA OKTAVIANA & X IPA 2 & 20 & 20 & 20 & 20 & 80 & 20,00 \\
\hline 69 & $\begin{array}{l}\text { MUHAMMAD INDRA FERI } \\
\text { FARONI }\end{array}$ & X IPA 2 & 20 & 18 & 17 & 24 & 79 & 19,75 \\
\hline 70 & M. IDRIS IFANSYAH & X IPA 2 & 20 & 20 & 19 & 27 & 86 & 21,50 \\
\hline 71 & $\begin{array}{l}\text { MUHAMMAD KHAIRUL } \\
\text { IHWAN }\end{array}$ & X IPA 2 & 20 & 20 & 18 & 24 & 82 & 20,50 \\
\hline 72 & NOVITA ANGGRAINI & X IPA 2 & 19 & 20 & 16 & 24 & 79 & 19,75 \\
\hline 73 & NURUL ATIKA & X IPA 2 & 20 & 20 & 20 & 24 & 84 & 21,00 \\
\hline 74 & RABIATUL HADAWIYAH & X IPA 2 & 16 & 18 & 18 & 22 & 74 & 18,50 \\
\hline 75 & RAHMAWATI & X IPA 2 & 14 & 17 & 17 & 23 & 71 & 17,75 \\
\hline 76 & ROFIKAH AENI & X IPA 2 & 18 & 19 & 18 & 20 & 75 & 18,75 \\
\hline 77 & SRI HANDAYANI & X IPA 2 & 20 & 20 & 18 & 18 & 76 & 19,00 \\
\hline 78 & SUPRIADI & X IPA 2 & 20 & 20 & 25 & 25 & 90 & 22,50 \\
\hline 79 & $\begin{array}{l}\text { SITI NURLAILY KUMALA } \\
\text { DEWI }\end{array}$ & X IPA 2 & 20 & 20 & 25 & 25 & 90 & 22,50 \\
\hline 80 & SITI RUKYAH & X IPA 2 & 15 & 20 & 18 & 20 & 73 & 18,25 \\
\hline 81 & TANTOWI YAHYA & X IPA 2 & 20 & 20 & 19 & 24 & 83 & 20,75 \\
\hline 82 & WANDA SAFITRI & X IPA 2 & 20 & 20 & 27 & 26 & 93 & 23,25 \\
\hline 83 & ABD. HARIS AL-WASI'I & X IPA 2 & 19 & 20 & 18 & 24 & 81 & 20,25 \\
\hline & Jumlah & & 1582 & 1520 & 1795 & 1955 & 6989 & 1744,75 \\
\hline & Rata-rata & & 19,06 & 18,31 & 21,62 & 23,55 & 84,20 & 21,021 \\
\hline
\end{tabular}

Data hasil olahan: tanggal $18-25$ Oktober 2020

Keterangan :

$1=\mathrm{EYD}$

$2=$ Penggunaan Imbuhan Pada Kata

$3=$ penggunaan imbuhan pada frasa

$4=$ penggunaan imbuhan pada kalimat

Aspek EYD dan penggunaan imbuhan pada kata, skor perolehan 0 - 20 sedangkan aspek penggunaan imbuhan pada frasa dan kalimat skor perolehan $0-30$.

Penilaian kemampuan siswa kelas IV SDN 22 MATARAM tahun pelajaran 2020/2021 tentang penggunaan imbuhan terdiri dari 4 aspek yaitu; (1) penggunaan EYD, (2) penggunaan imbuhan pada kata, (3) penggunaan imbuhan pada frasa, (4) penggunaan imbuhan pada kalimat. Aspek penilaian EYD dan penggunaan imbuhan pada kata skor perolehan 0-20, sedangkan aspek penilaian penggunaan imbuhan pada frasa dan penggunaan imbuhan pada kalimat skor perolehan 0-30. Sehingga jumlah skor perolehan 100.

Dari tabel di atas tampak bahwa kemampuan penggunaan imbuhan siswa pada aspek EYD diperoleh jumlah 1582 dengan ratarata 19,06. Aspek penggunaan imbuhan pada kata skor perolehan 1520 dengan rata-rata 18,31 . Aspek penggunaan imbuhan pada frasa skor perolehan 1795 dengan rata-rata 21,62, dan aspek penggunaan imbuhan pada kalimat skor perolehan 
1955 dengan rata-rata 23,55, sedangkan skor keseluruhan perolehan kemampuan penggunaan imbuhan adalah 6989 dengan rata-rata 84,20.

Tabel 02. Data Nilai Kemampuan Siswa Kelas IV SDN 22 MATARAM tentang Penggunaan Kata Depan.

\begin{tabular}{|c|c|c|c|c|c|c|c|c|}
\hline \multirow{3}{*}{ No } & \multirow{3}{*}{ Nama Siswa } & \multirow{3}{*}{ Kelas } & \multicolumn{4}{|c|}{ Aspek Penilaian } & \multirow{3}{*}{ Jml } & \multirow{3}{*}{$\begin{array}{c}\text { Rata- } \\
\text { rata }\end{array}$} \\
\hline & & & 1 & 2 & 3 & 4 & & \\
\hline & & & 0-20 & 0-20 & 0-30 & 0-30 & & \\
\hline 1 & AFIATUL HAIFAH & X IPA 1 & 20 & 20 & 28 & 26 & 94 & 23,50 \\
\hline 2 & BQ. NIHAL URWA & X IPA 1 & 20 & 20 & 25 & 25 & 90 & 22,50 \\
\hline 3 & DEVI ANGGUN & X IPA 1 & 20 & 20 & 25 & 24 & 89 & 22,25 \\
\hline 4 & FARIZAL RAMADHAN & X IPA 1 & 20 & 18 & 19 & 25 & 82 & 20,50 \\
\hline 5 & IRMA RAHMANI & X IPA 1 & 16 & 19 & 20 & 20 & 75 & 18,75 \\
\hline 6 & I'IN RAHMAWATI & X IPA 1 & 20 & 20 & 22 & 18 & 80 & 20,00 \\
\hline 7 & $\begin{array}{l}\text { LALU PRADIPTA NUR } \\
\text { IRFANI }\end{array}$ & X IPA 1 & 20 & 20 & 24 & 28 & 92 & 23,00 \\
\hline 8 & MUHAMMAD ZIYADI & X IPA 1 & 18 & 18 & 22 & 23 & 81 & 20,25 \\
\hline 9 & MUHAMMAD UBAEDI & X IPA 1 & 20 & 18 & 24 & 25 & 87 & 21,75 \\
\hline 10 & MIHAN & X IPA 1 & 20 & 19 & 22 & 24 & 85 & 21,25 \\
\hline 11 & $\begin{array}{l}\text { MUHAMMAD BASTIAN } \\
\text { ALI }\end{array}$ & X IPA 1 & 20 & 20 & 25 & 26 & 91 & 22,75 \\
\hline 12 & MUHAMMAD RIDHO & X IPA 1 & 20 & 20 & 21 & 26 & 87 & 21,75 \\
\hline 13 & NINI INDRIYANI & X IPA 1 & 18 & 20 & 25 & 20 & 83 & 20,75 \\
\hline 14 & NOVIA INDRAWATI & X IPA 1 & 20 & 20 & 22 & 28 & 90 & 22,50 \\
\hline 15 & NINING FUJI DIAR & X IPA 1 & 20 & 20 & 22 & 28 & 90 & 22,50 \\
\hline 16 & ROLI ADITIYA & X IPA 1 & 16 & 20 & 23 & 21 & 80 & 20,00 \\
\hline 17 & ROHILLIANI WINA SASKIA & X IPA 1 & 20 & 18 & 28 & 28 & 94 & 23,50 \\
\hline 18 & RIZQI JUNI ASRI & X IPA 1 & 15 & 18 & 20 & 26 & 79 & 19,75 \\
\hline 19 & SA'ADATUL AINI & X IPA 1 & 20 & 20 & 28 & 29 & 97 & 24,25 \\
\hline 20 & SITI ROHANIAH & X IPA 1 & 19 & 20 & 21 & 26 & 86 & 21,50 \\
\hline 21 & $\begin{array}{l}\text { SYLVIA LARANTIKA } \\
\text { PRATIWI }\end{array}$ & X IPA 1 & 20 & 20 & 30 & 28 & 98 & 24,50 \\
\hline 22 & TIA HANDAYANI & X IPA 1 & 20 & 20 & 30 & 27 & 97 & 24,25 \\
\hline 23 & NURHASANAH & X IPA 1 & 20 & 20 & 25 & 27 & 92 & 23,00 \\
\hline 24 & AHMAD ALI SYA'BANA & X IPA 1 & 20 & 20 & 26 & 24 & 90 & 22,50 \\
\hline 25 & ALI AKBAR RAFSANJANI & X IPA 1 & 16 & 18 & 20 & 24 & 78 & 19,50 \\
\hline 26 & ARMAN MAULANA & X IPA 1 & 14 & 18 & 20 & 24 & 76 & 19,00 \\
\hline 27 & AINAYAL AL FATIHA & X IPA 1 & 20 & 20 & 19 & 19 & 78 & 19,50 \\
\hline 28 & DHEVIA AURELIA & X IPA 1 & 15 & 20 & 20 & 22 & 77 & 19,25 \\
\hline 29 & ELYZA DIANTARI & X IPA 1 & 20 & 18 & 20 & 21 & 79 & 19,75 \\
\hline 30 & KHAIRUNNIDA & X IPA 1 & 20 & 18 & 20 & 21 & 79 & 19,75 \\
\hline 31 & MULIANI & X IPA 1 & 18 & 20 & 24 & 21 & 83 & 20,75 \\
\hline 32 & $\begin{array}{l}\text { MUHAMMAD BURHAN } \\
\text { AZZIS }\end{array}$ & X IPA 1 & 16 & 19 & 20 & 24 & 79 & 19,75 \\
\hline
\end{tabular}




\begin{tabular}{|c|c|c|c|c|c|c|c|c|}
\hline \multirow{3}{*}{ No } & \multirow{3}{*}{ Nama Siswa } & \multirow{3}{*}{ Kelas } & \multicolumn{4}{|c|}{ Aspek Penilaian } & \multirow{3}{*}{ Jml } & \multirow{3}{*}{$\begin{array}{l}\text { Rata- } \\
\text { rata }\end{array}$} \\
\hline & & & 1 & 2 & 3 & 4 & & \\
\hline & & & $\mathbf{0 - 2 0}$ & $\mathbf{0 - 2 0}$ & 0-30 & $0-30$ & & \\
\hline 33 & M. SOPYAN KHOLID & X IPA 1 & 18 & 20 & 24 & 22 & 84 & 21,00 \\
\hline 34 & MAWADDAH & X IPA 1 & 20 & 20 & 24 & 21 & 85 & 21,25 \\
\hline 35 & PUTRI JANUARTI & X IPA 1 & 18 & 18 & 24 & 24 & 84 & 21,00 \\
\hline 36 & RUHUL AINI & X IPA 1 & 20 & 18 & 22 & 20 & 80 & 20,00 \\
\hline 37 & RINA RIZKIANI & X IPA 1 & 20 & 20 & 24 & 28 & 92 & 23,00 \\
\hline 38 & ROSI ANJANI & X IPA 1 & 18 & 20 & 21 & 18 & 77 & 19,25 \\
\hline 39 & SUKMAWATI & X IPA 1 & 20 & 19 & 24 & 25 & 88 & 22,00 \\
\hline 40 & SYAUFRIANDA FAUZI & X IPA 1 & 20 & 18 & 22 & 25 & 85 & 21,25 \\
\hline 41 & SITI AYU AZHARY & X IPA 1 & 18 & 20 & 22 & 20 & 80 & 20,00 \\
\hline 42 & SYAMSUL HIDAYAT & X IPA 2 & 19 & 20 & 21 & 27 & 87 & 21,75 \\
\hline 43 & SAEPUL AZIS & X IPA 2 & 19 & 20 & 22 & 26 & 87 & 21,75 \\
\hline 44 & ULFA SARARESVIA & X IPA 2 & 18 & 20 & 24 & 28 & 90 & 22,50 \\
\hline 45 & ISTIHADAH & X IPA 2 & 18 & 20 & 22 & 24 & 84 & 21,00 \\
\hline 46 & $\begin{array}{l}\text { SAGITA AYU } \\
\text { RAMADIANTI }\end{array}$ & X IPA 2 & 18 & 20 & 20 & 18 & 76 & 19,00 \\
\hline 47 & ABDUL HAMID & X IPA 2 & 18 & 20 & 27 & 22 & 87 & 21,75 \\
\hline 48 & ADRIAN MAULANA & X IPA 2 & 20 & 20 & 22 & 23 & 85 & 21,25 \\
\hline 49 & AZIZAH & X IPA 2 & 18 & 20 & 18 & 18 & 74 & 18,50 \\
\hline 50 & ALAMSAH & X IPA 2 & 16 & 18 & 20 & 24 & 78 & 19,50 \\
\hline 51 & BAIQ YUDHIA IHROMI & X IPA 2 & 20 & 20 & 24 & 22 & 86 & 21,50 \\
\hline 52 & DIMAS HIJARWADI & X IPA 2 & 20 & 20 & 22 & 26 & 88 & 22,00 \\
\hline 53 & ELMANIA MONICA & X IPA 2 & 18 & 16 & 23 & 24 & 81 & 20,25 \\
\hline 54 & FITRIANI & X IPA 2 & 20 & 20 & 18 & 20 & 78 & 19,50 \\
\hline 55 & HENDRI HIDAYAT & X IPA 2 & 19 & 18 & 20 & 21 & 78 & 19,50 \\
\hline 56 & HASBIBULLAH & X IPA 2 & 18 & 20 & 21 & 28 & 87 & 21,75 \\
\hline 57 & ISMADIANA & X IPA 2 & 18 & 16 & 20 & 26 & 80 & 20,00 \\
\hline 58 & JUNIAWAN MULIADI & X IPA 2 & 18 & 16 & 22 & 24 & 80 & 20,00 \\
\hline 59 & KIKI APRILIA & X IPA 2 & 18 & 20 & 22 & 20 & 80 & 20,00 \\
\hline 60 & LUKMAN HADI & X IPA 2 & 20 & 20 & 18 & 18 & 76 & 19,00 \\
\hline 61 & $\begin{array}{l}\text { MUHAMMAD UMAR } \\
\text { SOPIANTO }\end{array}$ & X IPA 2 & 20 & 18 & 26 & 26 & 90 & 22,50 \\
\hline 62 & MAIL MARSAKIAWAN & X IPA 2 & 20 & 19 & 20 & 24 & 83 & 20,75 \\
\hline 63 & MUHAMMAD FAIZI & X IPA 2 & 19 & 18 & 24 & 25 & 86 & 21,50 \\
\hline 64 & MUHAMMAD SODIKIN & X IPA 2 & 19 & 20 & 26 & 20 & 85 & 21,25 \\
\hline 65 & MUHAMMAD FIKRI & X IPA 2 & 20 & 18 & 20 & 20 & 78 & 19,50 \\
\hline 66 & $\begin{array}{l}\text { MUHAMMAD TAUFIQ } \\
\text { HIDAYAT }\end{array}$ & X IPA 2 & 19 & 20 & 18 & 22 & 79 & 19,75 \\
\hline 67 & M. YAZID HAKIM & X IPA 2 & 18 & 20 & 26 & 23 & 87 & 21,75 \\
\hline 68 & MUTIA OKTAVIANA & X IPA 2 & 19 & 20 & 28 & 20 & 87 & 21,75 \\
\hline 69 & $\begin{array}{l}\text { MUHAMMAD INDRA FERI } \\
\text { FARONI }\end{array}$ & X IPA 2 & 18 & 18 & 21 & 20 & 77 & 19,25 \\
\hline 70 & M. IDRIS IFANSYAH & X IPA 2 & 20 & 20 & 24 & 28 & 92 & 23,00 \\
\hline
\end{tabular}




\begin{tabular}{|c|c|c|c|c|c|c|c|c|}
\hline \multirow{3}{*}{ No } & \multirow{3}{*}{ Nama Siswa } & \multirow{3}{*}{ Kelas } & \multicolumn{4}{|c|}{ Aspek Penilaian } & \multirow{3}{*}{ Jml } & \multirow{3}{*}{$\begin{array}{c}\text { Rata- } \\
\text { rata }\end{array}$} \\
\hline & & & 1 & 2 & 3 & 4 & & \\
\hline & & & 0-20 & 0-20 & 0-30 & 0-30 & & \\
\hline 71 & $\begin{array}{l}\text { MUHAMMAD KHAIRUL } \\
\text { IHWAN }\end{array}$ & X IPA 2 & 16 & 18 & 21 & 24 & 79 & 19,75 \\
\hline 72 & NOVITA ANGGRAINI & X IPA 2 & 16 & 19 & 20 & 25 & 80 & 20,00 \\
\hline 73 & NURUL ATIKA & X IPA 2 & 18 & 20 & 18 & 24 & 80 & 20,00 \\
\hline 74 & RABIATUL HADAWIYAH & X IPA 2 & 16 & 18 & 22 & 22 & 78 & 19,50 \\
\hline 75 & RAHMAWATI & X IPA 2 & 20 & 18 & 22 & 22 & 82 & 20,50 \\
\hline 76 & ROFIKAH AENI & X IPA 2 & 20 & 20 & 24 & 26 & 90 & 22,50 \\
\hline 77 & SRI HANDAYANI & X IPA 2 & 14 & 18 & 24 & 20 & 76 & 19,00 \\
\hline 78 & SUPRIADI & X IPA 2 & 18 & 20 & 20 & 25 & 83 & 20,75 \\
\hline 79 & $\begin{array}{l}\text { SITI NURLAILY KUMALA } \\
\text { DEWI }\end{array}$ & X IPA 2 & 18 & 20 & 25 & 26 & 89 & 22,25 \\
\hline 80 & SITI RUKYAH & X IPA 2 & 20 & 18 & 16 & 20 & 74 & 18,50 \\
\hline \multicolumn{2}{|c|}{ Jumlah } & & 1529 & 1594 & 1868 & 1961 & 6959 & 1739,75 \\
\hline \multicolumn{2}{|c|}{ Rata-rata } & & 18,42 & 19,20 & 22,50 & 23,62 & 83,84 & 20,96 \\
\hline
\end{tabular}

Data hasil olahan: tanggal $18-25$ Oktober 2020.

Keterangan :

$1=$ EYD

$2=$ Penggunaan Imbuhan antar Frasa

$3=$ penggunaan imbuhan antar klausa

$4=$ penggunaan imbuhan antar kalimat

Aspek EYD dan penggunaan kata depan antar frasa skor perolehan 0 - 20 sedangkan aspek penggunaan kata depan antar klausa dan penggunaan kata depan antar kalimat skor perolehan $0-30$.

Penilaian kemampuan siswa kelas IV SDN 22 MATARAM tentang penggunaan kata depan terdiri dari 4 aspek yaitu; (1) penggunaan EYD, (2) penggunaan kata depan antar frasa, (3) penggunaan kata depan antar klausa, dan (4) penggunaan kata depan antar kalimat. Aspek penilaian penggunaan EYD dan penggunaan kata

Tabel 03. Data Nilai Siswa Kelas IV SDN 22 MATARAM dalam Membedakan Imbuhan dengan Kata Depan.

\begin{tabular}{|c|c|c|c|c|c|c|}
\hline \multirow{2}{*}{ No } & \multirow{2}{*}{ Nama Siswa } & \multirow{2}{*}{ Kelas } & \multicolumn{2}{|c|}{ Aspek Penilaian } & \multirow{2}{*}{ Jml } & $\begin{array}{c}\text { Rata- } \\
\text { Rata }\end{array}$ \\
\cline { 4 - 5 } & & & Imbuhan & Kata Depan & & 86 \\
\hline 1 & AFIATUL HAIFAH & X IPA 1 & 93 & 179 & 89,50 \\
\hline 2 & BQ. NIHAL URWA & X IPA 1 & 77 & 78 & 155 & 77,50 \\
\hline 3 & DEVI ANGGUN & X IPA 1 & 95 & 85 & 180 & 90,00 \\
\hline 4 & FARIZAL RAMADHAN & X IPA 1 & 97 & 94 & 191 & 95,50 \\
\hline 5 & IRMA RAHMANI & X IPA 1 & 99 & 90 & 189 & 94,50 \\
\hline 6 & I'IN RAHMAWATI & X IPA 1 & 95 & 89 & 184 & 92,00 \\
\hline
\end{tabular}

depan antar frasa skor perolehan 0-20, sedangkan aspek penggunaan kata depan antar klausa dan penggunaan kata depan antar kalimat skor perolehan 0-30. Sehingga jumlah skor perolehan 100 .

Dari tabel di atas tampak bahwa kemampuan penggunaan kata depan siswa pada aspek EYD skor perolehan 1529 dengan rata-rata 18,42 . Aspek penggunaan kata depan antar frasa skor perolehan 1594 dengan rata-rata 19,20. Aspek penggunaan kata depan antar klausa skor perolehan 1868 dengan rata-rata 22,50. Aspek penggunaan kata depan antar kalimat skor perolehan 1961 dengan rata-rata 23,62. Sedangkan skor keseluruhan perolehan kemampuan penggunaan kata depan adalah 6959 dengan rata-rata 83,84 . 


\begin{tabular}{|c|c|c|c|c|c|c|}
\hline \multirow{2}{*}{ No } & \multirow{2}{*}{ Nama Siswa } & \multirow{2}{*}{ Kelas } & \multicolumn{2}{|c|}{ Aspek Penilaian } & \multirow{2}{*}{ Jml } & \multirow{2}{*}{$\begin{array}{l}\text { Rata- } \\
\text { Rata }\end{array}$} \\
\hline & & & Imbuhan & Kata Depan & & \\
\hline 7 & $\begin{array}{l}\text { LALU PRADIPTA NUR } \\
\text { IRFANI }\end{array}$ & X IPA 1 & 85 & 82 & 167 & 83,50 \\
\hline 8 & MUHAMMAD ZIYADI & X IPA 1 & 70 & 75 & 145 & 72,50 \\
\hline 9 & MUHAMMAD UBAEDI & X IPA 1 & 99 & 80 & 179 & 89,50 \\
\hline 10 & MIHAN & X IPA 1 & 94 & 92 & 186 & 93,00 \\
\hline 11 & $\begin{array}{l}\text { MUHAMMAD BASTIAN } \\
\text { ALI }\end{array}$ & X IPA 1 & 78 & 81 & 159 & 79,50 \\
\hline 12 & MUHAMMAD RIDHO & X IPA 1 & 95 & 87 & 182 & 91,00 \\
\hline 13 & NINI INDRIYANI & X IPA 1 & 79 & 85 & 164 & 82,00 \\
\hline 14 & NOVIA INDRAWATI & X IPA 1 & 90 & 91 & 181 & 90,50 \\
\hline 15 & NINING FUJI DIAR & X IPA 1 & 87 & 87 & 174 & 87,00 \\
\hline 16 & ROLI ADITIYA & X IPA 1 & 91 & 83 & 174 & 87,00 \\
\hline 17 & ROHILLIANI WINA SASKIA & X IPA 1 & 99 & 90 & 189 & 94,50 \\
\hline 18 & RIZQI JUNI ASRI & X IPA 1 & 99 & 90 & 189 & 94,50 \\
\hline 19 & SA'ADATUL AINI & X IPA 1 & 81 & 80 & 161 & 80,50 \\
\hline 20 & SITI ROHANIAH & X IPA 1 & 99 & 94 & 193 & 96,50 \\
\hline 21 & $\begin{array}{l}\text { SYLVIA LARANTIKA } \\
\text { PRATIWI }\end{array}$ & X IPA 1 & 74 & 79 & 153 & 76,50 \\
\hline 22 & TIA HANDAYANI & X IPA 1 & 99 & 97 & 196 & 98,00 \\
\hline 23 & NURHASANAH & X IPA 1 & 92 & 86 & 178 & 89,00 \\
\hline 24 & AHMAD ALI SYA'BANA & X IPA 1 & 98 & 98 & 196 & 98,00 \\
\hline 25 & ALI AKBAR RAFSANJANI & X IPA 1 & 98 & 97 & 195 & 97,50 \\
\hline 26 & ARMAN MAULANA & X IPA 1 & 98 & 92 & 190 & 95,00 \\
\hline 27 & AINAYAL AL FATIHA & X IPA 1 & 94 & 90 & 184 & 92,00 \\
\hline 28 & DHEVIA AURELIA & X IPA 1 & 77 & 78 & 155 & 77,50 \\
\hline 29 & ELYZA DIANTARI & X IPA 1 & 74 & 76 & 150 & 75,00 \\
\hline 30 & KHAIRUNNIDA & X IPA 1 & 84 & 78 & 162 & 81,00 \\
\hline 31 & MULIANI & X IPA 1 & 75 & 77 & 152 & 76,00 \\
\hline 32 & $\begin{array}{l}\text { MUHAMMAD BURHAN } \\
\text { AZZIS }\end{array}$ & X IPA 1 & 79 & 79 & 158 & 79,00 \\
\hline 33 & M. SOPYAN KHOLID & X IPA 1 & 78 & 79 & 157 & 78,50 \\
\hline 34 & MAWADDAH & X IPA 1 & 77 & 83 & 160 & 80,00 \\
\hline 35 & PUTRI JANUARTI & X IPA 1 & 86 & 79 & 165 & 82,50 \\
\hline 36 & RUHUL AINI & X IPA 1 & 82 & 84 & 166 & 83,00 \\
\hline 37 & RINA RIZKIANI & X IPA 1 & 77 & 85 & 162 & 81,00 \\
\hline 38 & ROSI ANJANI & X IPA 1 & 78 & 84 & 162 & 81,00 \\
\hline 39 & SUKMAWATI & X IPA 1 & 80 & 80 & 160 & 80,00 \\
\hline 40 & SYAUFRIANDA FAUZI & X IPA 1 & 94 & 92 & 186 & 93,00 \\
\hline 41 & SITI AYU AZHARY & X IPA 1 & 76 & 77 & 153 & 76,50 \\
\hline 42 & SYAMSUL HIDAYAT & X IPA 2 & 78 & 88 & 166 & 83,00 \\
\hline 43 & SAEPUL AZIS & X IPA 2 & 81 & 85 & 166 & 83,00 \\
\hline 44 & ULFA SARARESVIA & X IPA 2 & 79 & 80 & 159 & 79,50 \\
\hline 45 & ISTIHADAH & X IPA 2 & 84 & 87 & 171 & 85,50 \\
\hline
\end{tabular}




\begin{tabular}{|c|c|c|c|c|c|c|}
\hline \multirow{2}{*}{ No } & \multirow{2}{*}{ Nama Siswa } & \multirow{2}{*}{ Kelas } & \multicolumn{2}{|c|}{ Aspek Penilaian } & \multirow{2}{*}{ Jml } & \multirow{2}{*}{$\begin{array}{l}\text { Rata- } \\
\text { Rata }\end{array}$} \\
\hline & & & Imbuhan & Kata Depan & & \\
\hline 46 & $\begin{array}{l}\text { SAGITA AYU } \\
\text { RAMADIANTI }\end{array}$ & X IPA 2 & 85 & 87 & 172 & 86,00 \\
\hline 47 & ABDUL HAMID & X IPA 2 & 83 & 90 & 173 & 86,50 \\
\hline 48 & ADRIAN MAULANA & X IPA 2 & 84 & 84 & 168 & 84,00 \\
\hline 49 & AZIZAH & X IPA 2 & 80 & 76 & 156 & 78,00 \\
\hline 50 & ALAMSAH & X IPA 2 & 83 & 87 & 170 & 85,00 \\
\hline 51 & BAIQ YUDHIA IHROMI & X IPA 2 & 85 & 85 & 170 & 85,00 \\
\hline 52 & DIMAS HIJARWADI & X IPA 2 & 77 & 74 & 151 & 75,50 \\
\hline 53 & ELMANIA MONICA & X IPA 2 & 75 & 78 & 153 & 76,50 \\
\hline 54 & FITRIANI & X IPA 2 & 81 & 86 & 167 & 83,50 \\
\hline 55 & HENDRI HIDAYAT & X IPA 2 & 87 & 88 & 175 & 87,50 \\
\hline 56 & HASBIBULLAH & X IPA 2 & 77 & 81 & 158 & 79,00 \\
\hline 57 & ISMADIANA & X IPA 2 & 78 & 78 & 156 & 78,00 \\
\hline 58 & JUNIAWAN MULIADI & X IPA 2 & 77 & 78 & 155 & 77,50 \\
\hline 59 & KIKI APRILIA & X IPA 2 & 84 & 87 & 171 & 85,50 \\
\hline 60 & LUKMAN HADI & X IPA 2 & 80 & 80 & 160 & 80,00 \\
\hline 61 & $\begin{array}{l}\text { MUHAMMAD UMAR } \\
\text { SOPIANTO }\end{array}$ & X IPA 2 & 79 & 80 & 159 & 79,50 \\
\hline 62 & MAIL MARSAKIAWAN & X IPA 2 & 78 & 80 & 158 & 79,00 \\
\hline 63 & MUHAMMAD FAIZI & X IPA 2 & 79 & 76 & 155 & 77,50 \\
\hline 64 & MUHAMMAD SODIKIN & X IPA 2 & 91 & 90 & 181 & 90,50 \\
\hline 65 & MUHAMMAD FIKRI & X IPA 2 & 86 & 83 & 169 & 84,50 \\
\hline 66 & $\begin{array}{l}\text { MUHAMMAD TAUFIQ } \\
\text { HIDAYAT }\end{array}$ & X IPA 2 & 79 & 86 & 165 & 82,50 \\
\hline 67 & M. YAZID HAKIM & X IPA 2 & 81 & 85 & 166 & 83,00 \\
\hline 68 & MUTIA OKTAVIANA & X IPA 2 & 80 & 78 & 158 & 79,00 \\
\hline 69 & $\begin{array}{l}\text { MUHAMMAD INDRA FERI } \\
\text { FARONI }\end{array}$ & X IPA 2 & 79 & 79 & 158 & 79,00 \\
\hline 70 & M. IDRIS IFANSYAH & X IPA 2 & 86 & 87 & 173 & 86,50 \\
\hline 71 & $\begin{array}{l}\text { MUHAMMAD KHAIRUL } \\
\text { IHWAN }\end{array}$ & X IPA 2 & 82 & 87 & 169 & 84,50 \\
\hline 72 & NOVITA ANGGRAINI & X IPA 2 & 79 & 77 & 156 & 78,00 \\
\hline 73 & NURUL ATIKA & X IPA 2 & 84 & 92 & 176 & 88,00 \\
\hline 74 & RABIATUL HADAWIYAH & X IPA 2 & 74 & 79 & 153 & 76,50 \\
\hline 75 & RAHMAWATI & X IPA 2 & 71 & 80 & 151 & 75,50 \\
\hline 76 & ROFIKAH AENI & X IPA 2 & 75 & 80 & 155 & 77,50 \\
\hline 77 & SRI HANDAYANI & X IPA 2 & 76 & 78 & 154 & 77,00 \\
\hline 78 & SUPRIADI & X IPA 2 & 90 & 82 & 172 & 86,00 \\
\hline 79 & $\begin{array}{l}\text { SITI NURLAILY KUMALA } \\
\text { DEWI }\end{array}$ & X IPA 2 & 90 & 90 & 180 & 90,00 \\
\hline 80 & SITI RUKYAH & X IPA 2 & 73 & 76 & 149 & 74,50 \\
\hline 1 & AFIATUL HAIFAH & X IPA 1 & 83 & 83 & 166 & 83,00 \\
\hline 2 & BQ. NIHAL URWA & X IPA 1 & 93 & 89 & 182 & 91,00 \\
\hline 3 & DEVI ANGGUN & X IPA 1 & 81 & 74 & 155 & 77,50 \\
\hline
\end{tabular}




\begin{tabular}{|c|c|c|c|c|c|c|}
\hline \multirow{2}{*}{ No } & \multirow{2}{*}{ Nama Siswa } & \multirow{2}{*}{ Kelas } & \multicolumn{2}{|c|}{ Aspek Penilaian } & \multirow{2}{*}{ Jml } & \multirow{2}{*}{$\begin{array}{l}\text { Rata- } \\
\text { Rata }\end{array}$} \\
\hline & & & Imbuhan & Kata Depan & & \\
\hline & Jumlah & & 6989 & 6959 & 13938 & 6969,00 \\
\hline & Rata-rata & & 84,20 & 83,84 & 167,93 & 83,96 \\
\hline
\end{tabular}

Data hasil olahan: 18 - 25 Oktober 2020.

Data perbandingan nilai kemampuan siswa dalam membedakan penggunaan imbuhan dengan kata depan tersebut tampak bahwa jumlah dan rata-rata kemampuan membedakan kata depan lebih kecil daripada penggunaan imbuhan. Skor perolehan kemampuan penggunaan kata depan yaitu 6959 dengan rata-rata 83,84. Sedangkan skor perolehan kemampuan membedakan imbuhan yaitu 6989 dengan ratarata 84,20 . Sementara jumlah skor kemampuan rata-rata 167,93 .

Hasil Analisis Data dalam Penggunaan Imbuhan

$$
\begin{array}{ll}
\text { SMI=100 MI } & =1 / 2 \times \text { SMI } \\
\text { SDI } & =1 / 3 \times \text { MI } \\
& =1 / 2 \quad \times 100 \\
& =1 / 3 \times 50 \\
& =50 \\
& =16,67
\end{array}
$$

Pedoman Kategori Kemampuan Individu dalam Penggunaan Imbuhan

Kemampuan tinggi

$\mathrm{M}+1 \mathrm{SD}=50+16,67=66,67$

$$
\text { Kemampuan sedang }
$$

M- $1 \mathrm{SD}=50-16,67=33,33$

\section{Kemampuan rendah}

Kemampuan tinggi $=83$ orang $=83 / 83 \times 100 \%$ $=100 \%$

Kemampuan sedang $=$ tidak ada $=0 / 83 \times 100 \%=$ $0 \%$

Kemampuan rendah $=$ tidak ada $=0 / 83 \times 100 \%=$ $0 \%$

\footnotetext{
Hasil Indeks Prestasi kelompok dalam Penggunaan Imbuhan

IPK $=$ M/SMI x 100

Keterangan:

IPK = Indeks Prestasi Kelompok

$\mathrm{M}=$ Mean (nilai rata-rata)

SMI $=$ Skor Maksimal Ideal

$100=$ Bilangan tetap
}

$$
\begin{aligned}
\text { IPK } & =84,20 / 100 \times 100 \\
& =84,20
\end{aligned}
$$

Hasil Analisis Data dalam Penggunaan Kata Depan

$$
\begin{aligned}
\mathrm{SMI}=100 \quad \text { MI } & =1 / 2 \times \mathrm{SMI} \\
& \mathrm{SDI} \\
& =1 / 3 \times \mathrm{MI} \\
& =1 / 2 \times 100 \\
& =1 / 3 \times 50 \\
& =\quad 50 \\
& =16,67
\end{aligned}
$$

Pedoman Kategori Kemampuan Individu dalam Penggunaan Kata Depan

------- kemampuan tinggi

$\mathrm{M}+1 \mathrm{SDI}=50+16,67$

-------- kemampuan sedang

$\mathrm{M}-1 \mathrm{SDI}=50-16,67=33,33$

kemampuan rendah

Kemampuan tinggi $=83$ orang $=83 / 83 \times 100 \%=$ $100 \%$

Kemampuan sedang $=$ tidak ada $=0 / 83 \times 100 \%=$ $0 \%$

Kemampuan rendah $=$ tidak ada $=0 / 83 \times 100 \%=$ $0 \%$

Hasil Indeks Prestasi Kelompok dalam Penggunaan Kata Depan

IPK =M/SMI x 100

Keterangan:

IPK = Indeks Prestasi Kelompok

$\mathrm{M}=$ Mean (nilai rata-rata)

SMI = Skor Maksimal Ideal

$100=$ bilangan tetap

IPK $=83,84 / 100 \times 100$

$=83,84$

Dari analisis data di atas dapat disimpulkan bahwa, kemampuan siswa kelas IV SDN 22 MATARAM secara individu dalam membedakan imbuhan dengan kata depan dalam kalimat bahasa Indonesia cukup tinggi. Hal ini dapat kita lihat dari kategori kemampuan siswa 
secara individu, jumlah siswa yang memperoleh nilai di atas 66,67 dengan kategori kemampuan tinggi sebanyak 83 orang atau $100 \%$. Sedangkan siswa yang memperoleh nilai dengan kategori sedang dengan interval nilai antara 33,33 dan 66,67 sebanyak $0 \%$. secara klasikal diperoleh nilai rata- rata kelas 83,96 dengan indeks prestasi kelompok (IPK) dalam penggunaan imbuhan sebesar 84,20 dan indeks prestasi kelompok (IPK) dalam penggunaan kata depan sebesar 83,84 , ini termasuk kategori tinggi bila dibandingkan dengan target kurikulum dengan daya serap secara klaksikal minimal 75.

Nilai yang cukup tinggi diperoleh siswa ini baik secara individu maupun secara kelompok, disebabkan karena beberapa hal diantaranya:

a. Persiapan yang dilakukan oleh guru sebelum proses belajar mengajar cukup baik sehingga siswa termotivasi untuk belajar.

b. Pemahaman siswa dalam membedakan imbuhan dengan kata depan cukup baik sehingga kemampuan untuk membedakan imbuhan dengan kata depan tergolong tinggi.

Melalui data observasi, diperoleh hasil atau informasi bahwa dari 83 orang siswa yang dijadikan sampel penelitian sekitar $40 \%$ adalah siswa yang berprestasi dari Sekolah Dasar (SD) asal.

Analisis data lebih rinci dapat dilihat pada tabel- tabel analisis data kemampuan membedakan imbuhan dengan kata depan pada siswa kelas IV SDN 22 MATARAM.

Data penelitian yang telah dianalisis dan disajikan di atas , selanjutnya diadakan interpretasi data. Interpretasi data dalam penelitian ini dapat ditinjau dari beberapa segi dan faktor penyebab serta solusi atau upaya pemecahan masalah yang mengacu pada peningkatan pembelajaran membedakan imbuhan dengan kata depan dalam kalimat bahasa Indonesia.

Dari data hasil perolehan analisis kemampuan membedakan imbuhan dengan kata depan dalam kalimat bahasa Indonesia siswa kelas IV SDN 22 MATARAM tahun pelajaran 2020/2021 menunjukan bahwa skor nilai pembelajaran membedakan imbuhan dengan kata depan dalam kalimat bahasa Indonesia cukup tinggi. Skor nilai tertinggi pada pembelajaran membedakan imbuhan dengan kata depan diperoleh nilai 99. Skor nilai terendah 70. Dari segi kentuntasan belajar, membedakan imbuhan dengan kata depan dalam kalimat bahasa Indonesia siswa dapat dikatakan semua siswa tuntas belajarnya karena sudah mencapai kriteria kentuntasan minimal (KKM).

Dilihat dari segi ruang lingkup keluasan materi pembelajaran sebagai beban belajar siswa. Materi pembelajaran membedakan imbuhan dengan kata depan lebih luas karena mencakup multi variasi imbuhan dan kata depan yang ditulis dalam kalimat bahasa Indonesia. Dari segi valid dan realibel tes pembelajaran membedakan imbuhan dengan kata depan dalam kalimat bahasa Indonesia jauh lebih valid dan realibel. Dari segi objektifitas soal dan pengoreksian atau pemeriksaan hasil jawaban siswa, betul-betul objektif, lebih- lebih langsung diamati ketika pelaksanaan proses belajar mengajar berlangsung.

Menilik berbagai interpretasi dalam menyingkapi permasalahan kemampuan membedakan imbuhan dengan kata depan dalam kalimat bahasa Indonesia di atas mengisyaratkan para pendidik (guru), pemerintah, orang tua maupun masyarakat untuk bertanggung jawab dalam menangani semua permasalahan yang menyangkut kepentingan keberhasilan siswa. Upaya pemecahan secara umum adalah perlunya perubahan pelaksaan pendidikan itu sendiri, memperbaharui sistem manajemen pendidikan itu sendiri, memperbaharui sistem manajemen pengelola pendidikan dan perbaikan sistem pembelajaran bagi guru serta pemahaman bagi orang tua dalam menjaga kondisi belajar siswa di rumah. Secara khusus bagi guru (pendidik) perlu memperbaiki teknik mengajar membedakan imbuhan dengan kata depan dalam kalimat bahasa Indonesia. Disamping mampu memberikan evaluasi yang tepat dan efektif bagi kemajuan belajar siswa, guru juga perlu mengembangkan strategi mengajar. Jika siswa tidak mencapai kentuntasan belajar, guru harus mampu menyiapkan dan menjalankan program perbaikan yang tepat dan efektif, disamping memberikan pengayaan juga pada siswa yang berprestasi atau tuntas belajar. 
Berdasarkan hasil pengamatan keadaan sekolah layak untuk digunakan untuk proses belajar mengajar namun kekurangan kursi dan meja yang dapat mempengaruhi siswa untuk tidak fokus untuk belajar. Tapi semangat belajar siswa cukup tinggi dengan melihat hasil rata-rata perolehan skor mencapai hasil yang maksimal.

Khusus pada diri siswa 95\% orang tua murid/ wali murid bermata pencaharian petani musiman. Secara geografis orang tua masih membutuhkan tenaga anaknya dalam membantu menggarap ladang dan sawah, lebih-lebih menjelang musim hujan. Kebanyakan siswa tidak ada waktu untuk belajar di ruamah karena sibuk membantu orang tua di ladang maupun sawah. Di samping faktor ekonomi, gizi dan kesehatan dapat mempengaruhi keberhasilan siswa dalam belajar.

Cara bergaul anak di desa masih lugu dapat juga mempengaruhi tingkat kepekaan berpikir dan keberhasilan siswa dalam belajarnya. Jarak rumah siswa yang lumayan jauh yang menyebabkan anak-anak tidak biasa belajar berkelompok ataupun mengerjakan tugas kelompok.

Ada beberapa hal yang perlu mendapat perhatian dalam pembahasan hasil penelitian ini, yaitu:

(1) Hasil penelitian ini menunjukan bahwa nilai rata-rata (M) yang diperoleh siswa kelas IV SDN 22 MATARAM tahun pelajaran 2020/2021 pada pembelajaran membedakan imbuhan dengan kata depan dalam kalimat bahasa Indonesia termasuk dalam kategori tinggi. Hal ini menunjukan bahwa untuk mencapai tujuan pembelajaran membedakan imbuhan denagan kata depan dalam kalimat bahasa Indonesia yang maksimal diperlukan penguasaan dan pemahaman penguasaan bahasa Indonesia yang maksimal oleh siswa, disamping perubahan dan perbaikan system dan strategi pembelajaran oleh guru yang harus sesuai dengan kurikulum yang sedang berjalan. Demikian juga kerja sama pemerintah, orang tua, dan masyarakat setempat sangat dibutuhkan demi pencapaian keberhasilan belajar siswa baik pada pembelajaran membedakan imbuhan dengan kata depan maupun pada pelajaran yang lain.
Hasil analisis data menunjukan bahwa kemampuan membedakan imbuhan dengan kata depan dalam kalimat bahasa Indonesia siswa kelas kelas IV SDN 22 MATARAM tahun pelajaran 2020/2021 dapat dikatakan tuntas. Pada kemampuan menggunakan imbuhan yang dapat skor 90 ada 24 orang, skor 80 ada 28 orang, dan yang dapat skor 70 ada 31 orang siswa. Pada kemampuan menggunakan kata depan siswa yang dapat skor 90 ada 15 orang, dapat skor 80 ada 42 orang, dan yang dapat skor 70 ada 26 orang siswa. Perolehan hasil pembelajaran membedakan imbuhan dengan kata depan dalam kalimat bahasa Indonesia siswa kelas IV SDN 22 MATARAM tahun pelajaran 2020/2021 sangat dipengaruhi oleh faktor guru, orang tua, pemerintah, masyarakat, dan siswa itu sendiri. Hal ini berarti adanya peningkatan pembelajaran membedakan imbuhan dengan kata depan dalam kalimat bahasa Indonesia siswa kelas IV SDN 22 MATARAM tahun pelajaran 2020/2021 sangat signifikan. Hasil Analisis Data dalam Penggunaan Imbuhan

$$
\begin{array}{ll}
\text { SMI=100 MI } & =1 / 2 \times \text { SMI } \\
\text { SDI } & =1 / 3 \times \text { MI } \\
& =1 / 2 \quad \times 100 \\
& =1 / 3 \times 50 \\
& =50 \\
& =16,67
\end{array}
$$

Pedoman Kategori Kemampuan Individu dalam Penggunaan Imbuhan

--------- Kemampuan tinggi

$\mathrm{M}+1 \mathrm{SD}=50+16,67=66,67$ Kemampuan sedang

M- $1 \mathrm{SD}=50-16,67=33,33$

Kemampuan rendah

Kemampuan tinggi $=83$ orang $=83 / 83 \times 100 \%$ $=100 \%$

Kemampuan sedang $=$ tidak ada $=0 / 83 \times 100 \%=$ $0 \%$

Kemampuan rendah $=$ tidak ada $=0 / 83 \times 100 \%=$ $0 \%$

Hasil Indeks Prestasi kelompok dalam Penggunaan Imbuhan

IPK $=$ M/SMI x 100

Keterangan: 


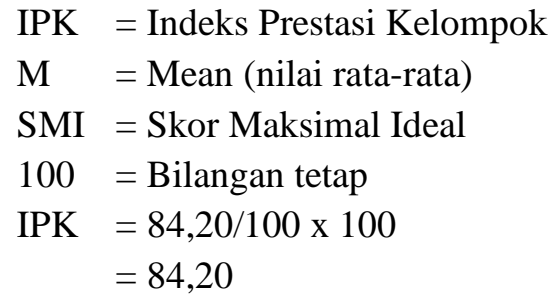

Hasil Analisis Data dalam Penggunaan Kata Depan

$$
\begin{array}{ll}
\text { SMI }=100 \quad \text { MI } & =1 / 2 \times \text { SMI } \\
& \text { SDI } \\
& =1 / 3 \times \text { MI } \\
& =1 / 2 \times 100 \\
& =1 / 3 \times 50 \\
& =16,67
\end{array}
$$

Pedoman Kategori Kemampuan Individu dalam Penggunaan Kata Depan
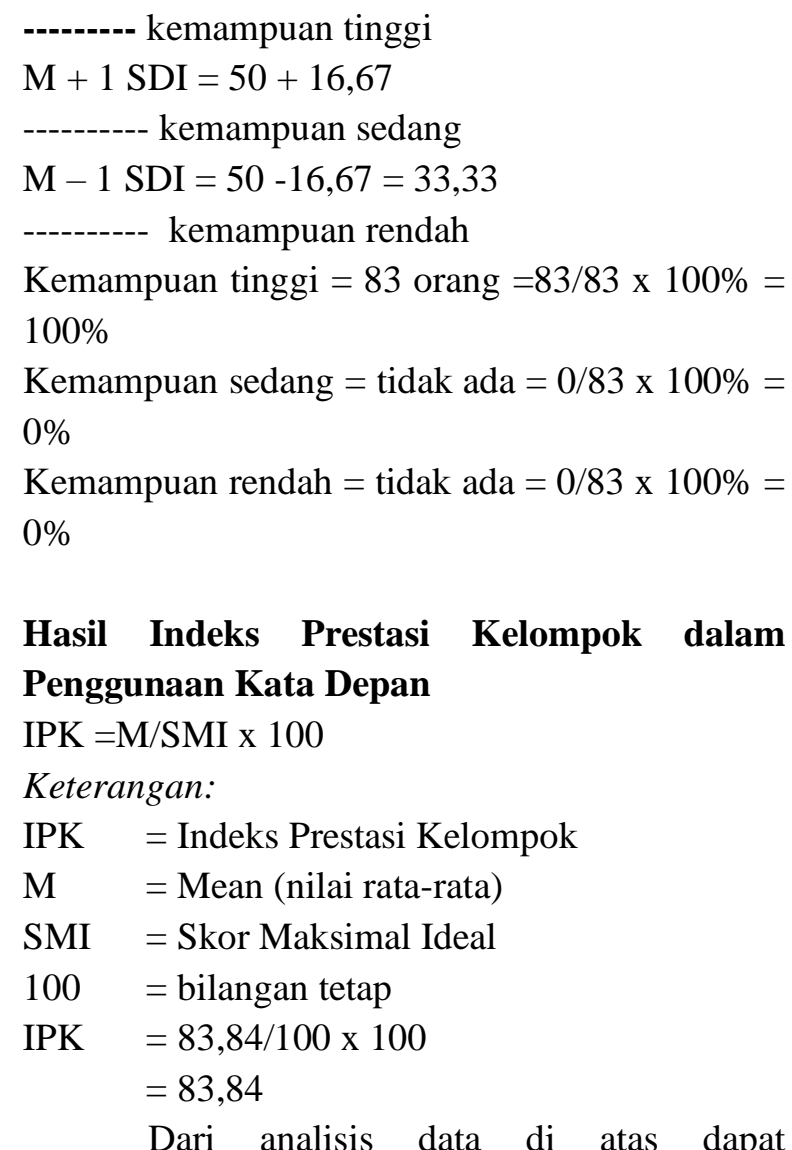
disimpulkan bahwa, kemampuan siswa kelas IV SDN 22 MATARAM secara individu dalam membedakan imbuhan dengan kata depan dalam kalimat bahasa Indonesia cukup tinggi. Hal ini dapat kita lihat dari kategori kemampuan siswa secara individu, jumlah siswa yang memperoleh nilai di atas 66,67 dengan kategori kemampuan tinggi sebanyak 83 orang atau $100 \%$. Sedangkan siswa yang memperoleh nilai dengan kategori sedang dengan interval nilai antara 33,33 dan 66,67 sebanyak $0 \%$. secara klasikal diperoleh nilai rata- rata kelas 83,96 dengan indeks prestasi kelompok (IPK) dalam penggunaan imbuhan sebesar 84,20 dan indeks prestasi kelompok (IPK) dalam penggunaan kata depan sebesar 83,84, ini termasuk kategori tinggi bila dibandingkan dengan target kurikulum dengan daya serap secara klaksikal minimal 75.

Nilai yang cukup tinggi diperoleh siswa ini baik secara individu maupun secara kelompok, disebabkan karena beberapa hal diantaranya:

c. Persiapan yang dilakukan oleh guru sebelum proses belajar mengajar cukup baik sehingga siswa termotivasi untuk belajar.

d. Pemahaman siswa dalam membedakan imbuhan dengan kata depan cukup baik sehingga kemampuan untuk membedakan imbuhan dengan kata depan tergolong tinggi.

Melalui data observasi, diperoleh hasil atau informasi bahwa dari 83 orang siswa yang dijadikan sampel penelitian sekitar $40 \%$ adalah siswa yang berprestasi dari Sekolah Dasar (SD) asal.

Analisis data lebih rinci dapat dilihat pada tabel- tabel analisis data kemampuan membedakan imbuhan dengan kata depan pada siswa kelas IV SDN 22 MATARAM.

Data penelitian yang telah dianalisis dan disajikan di atas, selanjutnya diadakan interpretasi data. Interpretasi data dalam penelitian ini dapat ditinjau dari beberapa segi dan faktor penyebab serta solusi atau upaya pemecahan masalah yang mengacu pada peningkatan pembelajaran membedakan imbuhan dengan kata depan dalam kalimat bahasa Indonesia.

Dari data hasil perolehan analisis kemampuan membedakan imbuhan dengan kata depan dalam kalimat bahasa Indonesia siswa kelas IV SDN 22 MATARAM tahun pelajaran 2020/2021 menunjukan bahwa skor nilai pembelajaran membedakan imbuhan dengan kata depan dalam kalimat bahasa Indonesia cukup tinggi. Skor nilai tertinggi pada pembelajaran membedakan imbuhan dengan kata depan diperoleh nilai 99. Skor nilai terendah 70. Dari segi kentuntasan belajar, membedakan imbuhan 
dengan kata depan dalam kalimat bahasa Indonesia siswa dapat dikatakan semua siswa tuntas belajarnya karena sudah mencapai kriteria kentuntasan minimal (KKM).

Dilihat dari segi ruang lingkup keluasan materi pembelajaran sebagai beban belajar siswa. Materi pembelajaran membedakan imbuhan dengan kata depan lebih luas karena mencakup multi variasi imbuhan dan kata depan yang ditulis dalam kalimat bahasa Indonesia. Dari segi valid dan realibel tes pembelajaran membedakan imbuhan dengan kata depan dalam kalimat bahasa Indonesia jauh lebih valid dan realibel. Dari segi objektifitas soal dan pengoreksian atau pemeriksaan hasil jawaban siswa, betul-betul objektif, lebih- lebih langsung diamati ketika pelaksanaan proses belajar mengajar berlangsung.

Menilik berbagai interpretasi dalam menyingkapi permasalahan kemampuan membedakan imbuhan dengan kata depan dalam kalimat bahasa Indonesia di atas mengisyaratkan para pendidik (guru), pemerintah, orang tua maupun masyarakat untuk bertanggung jawab dalam menangani semua permasalahan yang menyangkut kepentingan keberhasilan siswa. Upaya pemecahan secara umum adalah perlunya perubahan pelaksaan pendidikan itu sendiri, memperbaharui sistem manajemen pendidikan itu sendiri, memperbaharui sistem manajemen pengelola pendidikan dan perbaikan sistem pembelajaran bagi guru serta pemahaman bagi orang tua dalam menjaga kondisi belajar siswa di rumah. Secara khusus bagi guru (pendidik) perlu memperbaiki teknik mengajar membedakan imbuhan dengan kata depan dalam kalimat bahasa Indonesia. Disamping mampu memberikan evaluasi yang tepat dan efektif bagi kemajuan belajar siswa, guru juga perlu mengembangkan strategi mengajar. Jika siswa tidak mencapai kentuntasan belajar, guru harus mampu menyiapkan dan menjalankan program perbaikan yang tepat dan efektif, disamping memberikan pengayaan juga pada siswa yang berprestasi atau tuntas belajar.

Berdasarkan hasil pengamatan keadaan sekolah layak untuk digunakan untuk proses belajar mengajar namun kekurangan kursi dan meja yang dapat mempengaruhi siswa untuk tidak fokus untuk belajar. Tapi semangat belajar siswa cukup tinggi dengan melihat hasil rata-rata perolehan skor mencapai hasil yang maksimal.

Khusus pada diri siswa $95 \%$ orang tua murid/ wali murid bermata pencaharian petani musiman. Secara geografis orang tua masih membutuhkan tenaga anaknya dalam membantu menggarap ladang dan sawah, lebih-lebih menjelang musim hujan. Kebanyakan siswa tidak ada waktu untuk belajar di ruamah karena sibuk membantu orang tua di ladang maupun sawah. Di samping faktor ekonomi, gizi dan kesehatan dapat mempengaruhi keberhasilan siswa dalam belajar.

Cara bergaul anak di desa masih lugu dapat juga mempengaruhi tingkat kepekaan berpikir dan keberhasilan siswa dalam belajarnya. Jarak rumah siswa yang lumayan jauh yang menyebabkan anak-anak tidak biasa belajar berkelompok ataupun mengerjakan tugas kelompok.

Ada beberapa hal yang perlu mendapat perhatian dalam pembahasan hasil penelitian ini, yaitu:

(2) Hasil penelitian ini menunjukan bahwa nilai rata-rata (M) yang diperoleh siswa kelas IV SDN 22 MATARAM tahun pelajaran 2020/2021 pada pembelajaran membedakan imbuhan dengan kata depan dalam kalimat bahasa Indonesia termasuk dalam kategori tinggi. Hal ini menunjukan bahwa untuk mencapai tujuan pembelajaran membedakan imbuhan denagan kata depan dalam kalimat bahasa Indonesia yang maksimal diperlukan penguasaan dan pemahaman penguasaan bahasa Indonesia yang maksimal oleh siswa, disamping perubahan dan perbaikan system dan strategi pembelajaran oleh guru yang harus sesuai dengan kurikulum yang sedang berjalan. Demikian juga kerja sama pemerintah, orang tua, dan masyarakat setempat sangat dibutuhkan demi pencapaian keberhasilan belajar siswa baik pada pembelajaran membedakan imbuhan dengan kata depan maupun pada pelajaran yang lain. Hasil analisis data menunjukan bahwa kemampuan membedakan imbuhan dengan kata depan dalam kalimat bahasa Indonesia siswa kelas kelas IV SDN 22 MATARAM tahun pelajaran 
2020/2021 dapat dikatakan tuntas. Pada kemampuan menggunakan imbuhan yang dapat skor 90 ada 24 orang, skor 80 ada 28 orang, dan yang dapat skor 70 ada 31 orang siswa. Pada kemampuan menggunakan kata depan siswa yang dapat skor 90 ada 15 orang, dapat skor 80 ada 42 orang, dan yang dapat skor 70 ada 26 orang siswa. Perolehan hasil pembelajaran membedakan imbuhan dengan kata depan dalam kalimat bahasa Indonesia siswa kelas IV SDN 22 MATARAM tahun pelajaran 2020/2021 sangat dipengaruhi oleh faktor guru, orang tua, pemerintah, masyarakat, dan siswa itu sendiri. Hal ini berarti adanya peningkatan pembelajaran membedakan imbuhan dengan kata depan dalam kalimat bahasa Indonesia siswa kelas IV SDN 22 MATARAM tahun pelajaran 2020/2021 sangat signifikan.

\section{Penutup}

Berdasarkan penyajian dan analisis data diperoleh simpulan sebagai berikut :

(1) Secara umum rata-rata peningkatan pembelajaran membedakan imbuhan dengan kata depan dalam kalimat bahasa Indonesia siswa kelas IV SDN 22 MATARAM tahun pelajaran 2020/2021 termasuk dalam kategori tinggi. Hal ini ditunjukan dengan rata-rata (M) kemampuan individu dalam penggunaan imbuhan adalah 84,20. kemampuan kelompok atau IPK $=84,20$. Sedangkan kemampuan penggunaan kata depan ditunjukan dengan rata-rata(M) 83,84 dan kemampuan indeks prestasi kelompok $=$ 83,84 .

(2) Peningkatan pembelajaran membedakan imbuhan dengan kata depan dalam kalimat bahasa Indonesia siswa kelas IV SDN 22 MATARAM tahun pelajaran 2020/2021 sangat didukung oleh metode yang digunakan oleh pengajar. Disamping itu pemberian motivasi pada saat latihan pembelajaran membedakan imbuhan dengan kata depan sangat mendukung keberhasilan siswa.

(3) Kemampuan membedakan imbuhan dengan kata depan dalam kalimat bahasa Indonesia siswa kelas IV SDN 22 MATARAM tahun pelajaran 2020/2021 cukup tinggi karena indeks prestasi kelompok (IPK) yang dicapai sebesar 83,96. Persentase indeks prestasi kelompok termasuk kategori tinggi bila dikaitkan dengan target kurikulum dengan daya serap secara klasikal minimal 75 . Sedangkan kemampuan secara individu membedakan imbuhan dengan kata depan dalam kalimat bahasa Indonesia rata-rata semua siswa di atas $\mathrm{KKM}=66.67$ atau $100 \%$.

\section{Saran}

Berdasarkan simpulan penelitian di atas, dapat diajukan saran sebagai berikut:

(1) Kepada para guru, khususnya guru mata pelajaran bahasa Indonesia diharapkan agar hasil penelitian ini dimanfaatkan sebagai bahan acuan dalam memecahkan masalah yang terjadi, khususnya peningkatan pembelajaran membedakan imbuhan dengan kata depan dalam kalimat bahasa Indonesia pada siswa yaitu dengan meningkatkan peguasaan dan pemahaman siswa pada materi pembelajaran kalimat bahasa Indonesia dengan penekanan pada penggunaan kalimat bahasa Indonesia yang baik dan benar.

(2) Kepada semua pihak yang terlibat dalam dunia pendidikan seperti guru dan kepala sekolah supaya dapat menciptakan sistem belajar yang kondusif dengan memperhatikan faktor-faktor pendukung, aspirasi siswa dalam mempelajari bahasa Indonesia baik secara lisan maupun tulisan.

(3) Kepada orang tua diharapkan mampu memberikan motivasi dan dorongan belajar kepada anak di rumah.

(4) Kepada siswa diharapkan lebih menekuni pelajaran bahasa Indonesia, khususnya dalam menggunakan bahasa Indonesia yang baik dan benar. Baik pada aspek ketatabahasaan maupun keterampilan berbahasa lainnya seperti membaca, mendengar, berbicara, dan menulis. 
Bagi calon peneliti yang tertarik untuk melakukan penelitian lanjutan diharapkan agar hasil penelitian ini dimanfaatkan sebagai bahan acuan dalam melakukan penelitian lanjutan yang lebih luas cakupannya. Berdasarkan penyajian dan analisis data diperoleh simpulan sebagai berikut :

(4) Secara umum rata-rata peningkatan pembelajaran membedakan imbuhan dengan kata depan dalam kalimat bahasa Indonesia siswa kelas IV SDN 22 MATARAM tahun pelajaran 2020/2021 termasuk dalam kategori tinggi. Hal ini ditunjukan dengan rata-rata (M) kemampuan individu dalam penggunaan imbuhan adalah 84,20. kemampuan kelompok atau IPK $=84,20$. Sedangkan kemampuan penggunaan kata depan ditunjukan dengan rata-rata(M) 83,84 dan kemampuan indeks prestasi kelompok $=$ 83,84 .

(5) Peningkatan pembelajaran membedakan imbuhan dengan kata depan dalam kalimat bahasa Indonesia siswa kelas IV SDN 22 MATARAM tahun pelajaran 2020/2021 sangat didukung oleh metode yang digunakan oleh pengajar. Disamping itu pemberian motivasi pada saat latihan pembelajaran membedakan imbuhan dengan kata depan sangat mendukung keberhasilan siswa.

(6) Kemampuan membedakan imbuhan dengan kata depan dalam kalimat bahasa Indonesia siswa kelas IV SDN 22 MATARAM tahun pelajaran 2020/2021 cukup tinggi karena indeks prestasi kelompok (IPK) yang dicapai sebesar 83,96. Persentase indeks prestasi kelompok termasuk kategori tinggi bila dikaitkan dengan target kurikulum dengan daya serap secara klasikal minimal 75 . Sedangkan kemampuan secara individu membedakan imbuhan dengan kata depan dalam kalimat bahasa Indonesia rata-rata semua siswa di atas KKM =66.67 atau $100 \%$.

\section{Daftar Pustaka}

Alwi Hasan, dkk. 2003. Tata Bahasa Baku Bahasa Indonesia Edisi Ketiga. Jakarta: Balai Pustaka.
Arikunto, 1985. Proses Penelitian Suatu Pendekatan Praktis. Jakarta: Bima Dasar.

Badudu, J. S, 1980. Pelik-Pelik Bahasa Indonesia. Bandung: Pustaka

Chaer, Abdul. 2003. Seputar Tata Bahasa Baku Bahasa Indonesia. Jakarta: Rineka Cipta

Dekdikbud. 1989. Kamus Besar Bahasa Indonesia. Jakarta: Balai Pustaka. 1994. Pedoman Umum Ejaan Bahasa Indonesia yang Disempurnakan. Jakarta: Balai Pustaka

Depdiknas. 2008. TOT Guru Bahasa Indonesia, Ketrampilan Berbicara. NTB: Depdiknas

Dirjendirdasmen. 1994. Proses Pembelajaran sebagai Proses Pendidikan. Jakarta: grasindo

Keraf, Goryes. 1984. Tata Bahasa Indonesia. Ende Fores: Indah.

Kridalaksana, Harimurti. 1986. Kelas Kata Dalam Bahasa Indonesia. Jakarta: gramedia

1986. Pembentukan Kata Dalam Bahasa Indonesia. Jakarta: Balai Pustaka

Kisyani, Laksono. 1999. Teori Menulis. Surabaya: Unesa University Press.

Nasution. 2005. Tes dan Asesmen di SLTP. Jakarta: Universitas Terbuka

Nurkencana. 1986. Evaluasi Pendidikan. Jakarta: Usaha Nasional.

Ramlan. 1985. Ilmu Bahasa Indonesia Morfologi Suatu Tinjauan Deskriptif. Yogyakarta: CV. Karyono.

.1983. Kata Depan Atau Preposisi Dalam Bahasa Indonesia. Yogyakarta.:CV Karyono 
Riyanto, Yatim. 2001. Metodologi Penelitian. Surabaya: SIC

Sugiyono. 2000. Metode Penelitian Pendidikan Pendekatan Kuantitatif, Kualitatif, dan $R \& D$. Bandung: Alfabeta

Tarigan, Henri Guntur. 1987. Pengaturan Ejaan Bahasa Indonesia. Bandung: Angkasa. 
